\title{
Using conflict over risk management in the marine environment to strengthen measures of governance
}

\author{
$\underline{\text { Courtenay E. Parlee }}^{1,2}$ and Melanie G. Wiber ${ }^{1}$
}

\begin{abstract}
Management of and planning for the Canadian marine environment can be disrupted by conflict, but conflict is inevitable given the plurality of actors, interests, values, and uses of marine space. Unresolved conflict may impede governance objectives and threaten the sustainability of social-ecological systems. Innovative institutional arrangements such as adaptive comanagement theoretically reduce conflict and support sustainable management. The southwest New Brunswick Bay of Fundy Marine Advisory Committee (MAC) was assembled in 2004 to address conflict between marine users and to further marine planning. As an innovative planning institution influenced by comanagement theory, the MAC experience served as a case study to develop governance measures for the Canadian Fisheries Research Network Comprehensive Fisheries Sustainability Framework, which includes a consideration of ecological, social, economic, and governance dimensions of sustainability. One of the most important but neglected aspects of sustainability measurements involves the assessment of governance and planning effectiveness. An assessment of the MAC experience through a comprehensive sustainability evaluation framework offers significant lessons for advancing the theoretical and empirical literature on adaptive comanagement through deeper consideration of challenges in creating institutions of "good governance." In doing so, the case study also contributes to the Comprehensive Fisheries Sustainability Framework by testing some measures of governance effectiveness, including co-operation, resources, transparency, accountability, and inclusivity.
\end{abstract}

Key Words: adaptive co-management; conflict resolution; fisheries; governance; indicators; sustainability

\section{INTRODUCTION}

Planning around multiple uses of marine space is a global problem, and the Canadian waters of the Bay of Fundy are no exception, with commercial fisheries, aquaculture, shipping, marine protected areas, and tourism all competing for space. Conflict among these industries particularly escalated after aquaculture was introduced to the southwest New Brunswick nearshore in the 1980s. Throughout the subsequent decades, problems have included gear conflict leading to lobster "ghost traps" and whale entanglements in fishing line, sea lice pesticides from aquaculture killing nontarget species, and a significant increase in marine debris (Barnett et al. 2016, Parlee 2016). In 2013, tensions between fishermen and aquaculture operators culminated in a court case, and Kelly's Cove Salmon Ltd. was fined for violating the Fisheries Act (R.S.C., 1985) by illegally using a pesticide that contributed to lobster kills (Environment Canada 2013). It is these events that triggered the research that serves as the empirical foundation for this paper.

This coastal social-ecological system is subject to a complex organization of jurisdictions and bureaucracy. In Canada, The Fisheries Act (R.S.C., 1985, c. F-14) and the Oceans Act (S.C. 1996, c. 31) give extensive powers to the Minister of Fisheries and Oceans Canada to organize and regulate marine-human environmental interactions. However, the Oceans Act also stipulates that management must be done in collaboration with "other ministers, boards and agencies, with provincial and territorial government [and] with affected aboriginal organizations, coastal communities" (see also Pinkerton 1994, Melzer 1998). Thus, with respect to aquaculture, the federal government shares power with provinces such as New Brunswick through memorandums of understanding (Phyne 1996, Auditor General of Canada 2013, Wiber 2014). Similarly, policies such as the 2002 Oceans Strategy promote the active engagement of citizens in decisions that affect them by establishing participatory decision-making structures (Fisheries and Oceans Canada 2002).
Here, we examine the development of an institution created in the context of growing interest in organizations for adaptive comanagement. In 2004, both the Canadian federal and New Brunswick provincial fisheries departments collaborated to address conflict and improve planning for the southwest New Brunswick Bay of Fundy by creating an innovative institution called the Southwest New Brunswick Marine Resource Planning (MRP) initiative, which ultimately became a marine advisory committee (MAC). At the onset, the mandate of the MRP was to bring stakeholders together to develop a broad marine resource management plan for the coastal waters of southwest New Brunswick, as was consistent with adaptive comanagement literature (Pinkerton 1994, Carlsson and Berkes 2005, Olsson et al. 2004, Armitage et al. 2009). This broad objective shifted focus and breadth over the 14 years the organization was in existence, as will be further explained below.

We also evaluate the MRP/MAC as an adaptive comanagement institution by drawing analytical insight from a fisheries evaluation framework developed through the Canadian Fisheries Research Network (CFRN). In 2012, the CFRN was formed as a broad, 5-year collaboration between academics, government, and industry to address problems in Canadian fisheries (see http:// www.cfrn-rcrp.ca/Public-Home-EN). One project supported by the CFRN was the development of a comprehensive fisheries sustainability framework (hereafter referred to as the CFRN framework) to assess the sustainability of Canadian fishing sectors (see Stephenson et al. 2018a). This project was stimulated by several developments. First, in 2009, Fisheries and Oceans Canada had released its own sustainable fisheries framework, but with limited implementation (E. Angel, D. Edwards, S. Hawkshaw, C. Wor, and C. E. Parlee, unpublished manuscript). Other efforts to develop frameworks that both guide and assess the management and governance of marine activities (Bostrom 2012, Dahl 2012, Begg et al. 2015) have focused primarily on the ecological pillar (see Stephenson et al. 2018a,b). To address these 
problems, the CFRN developed the framework to recognize explicitly the four pillars of sustainability (ecological, social, economic, and institutional) and to suggest practical measures to assess progress toward sustainability (E. Angel, D. Edwards, S. Hawkshaw, C. Wor, and C. E. Parlee, unpublished manuscript).

The CFRN framework went through several versions (see Appendix 1 for one version) based on an iterative process of viewing international best practice and Canadian policy through Canadian case studies. The MRP/MAC was investigated as one such case study.

Here, we first describe the methods used in the MRP/MAC case study and then describe the various stages of development that the group underwent. Second, and with reference to sustainability literature, we explore how the analysis of the MRP/MAC case study contributed to indicators developed for the CFRN framework, especially around the neglected governance issues, including cooperation, governance resource requirements, transparency, accountability, and inclusivity. Third, out of the experience of developing framework indicators, we suggest lessons for improving organizations such as the MRP/MAC as participatory governance and comanagement institutions. Finally, with reference to the adaptive comanagement literature, we provide a deeper consideration of the challenges and roadblocks in creating innovative governance institutions in the Canadian context.

\section{METHODS}

The lead author of this paper undertook the MRP/MAC case study between 2011 and 2015. Four types of data were collected and included: (1) analysis of documents and records of meetings generated by the MRP/MAC and the Government Secretariat, (2) participant observation of five different MAC meetings, (3) 29 individual semi-structured interviews involving past and thenactive members of the MAC and of the Government Secretariat, and (4) two small focus group sessions. Using a grounded theory approach to textual analysis, the data were examined manually for relationships. Different categories, sources, and types of data were compared, and then data were tested against codes until the best possible explanation for a set of data was developed (following Lipton 2000, Charmaz 2006). While assembling data for this research, both authors were members of the CFRN and met regularly with CFRN members to discuss research results and implications of the data for the framework indicators.

\section{STAGES OF THE SOUTHWEST NEW BRUNSWICK MARINE RESOURCE PLANNING INITIATIVE/MARINE ADVISORY COMMITTEE}

The MRP/MAC went through several iterations between 2004 and 2017. It began life as a marine planning group (MRP) but later transitioned into a marine advisory group (MAC). In July 2017, the MAC was unilaterally cancelled by provincial and federal governments, with the joint announcement, "It has been determined that the current MAC structure and process have not met the expectations of government, or the committee membership," (in letter provided by a key informant: Letter to Southwest New Brunswick Marine Advisory Committee, circulated 11 July 2017 to members of the Southwest New Brunswick Marine Advisory Committee by the Regional Director of Ecosystem Management Branch, Fisheries and Oceans Canada Maritimes
Region, and the Provincial Director of Fisheries and Aquaculture Division, New Brunswick Department of Agriculture, Aquaculture and Fisheries). In what follows, we review these stages briefly.

In forming the MRP in 2004, the two levels of government (federal and provincial) drew together individuals from diverse backgrounds to address management and planning challenges associated with ongoing conflict (see http://bofmrp.ca/home/). The stakeholder groups included commercial fishing, fish processing, aquaculture, education, economic development, communities, conservation, and First Nations/Aboriginal government. Provincial and federal fisheries department representatives formed what was called the Government Secretariat, with a role to provide technical support to the group. The MRP/MAC was uniquely fashioned for southwest New Brunswick. However, there are other innovative institutions for adaptive comanagement that have been developed elsewhere in Canada, including the West Coast Vancouver Island Aquatic Management Board, which was established in 2001 by federal, provincial, Nuu-chah-nulth, and local governments.

In phase 1 of the MRP, members of the group explored the steps required to develop a marine resource plan to guide federal and provincial decisions for the coastal waters of southwest New Brunswick. In phase 2, they reached out to members of communities in southwest New Brunswick, specifically to understand better the local values that would come into play in assessing management plans or development projects. The result was a unique community values criteria (CVC) tool to provide decision support for evaluating and approving or rejecting proposals and plans for the area. In phase 3, there were consultations on how to operationalize the CVC tool, and it was at that point that discussions began about whether the planning group should take the form of a decision-making or advisory body. The MRP members recommended that the two levels of government create a marine planning advisory council, which, among other things, would have the ability to accept and examine any proposals for marine activities and provide "open explicit advice" on issues related to development and management (MRPP Committee 2009:22). However, the government members who made up the Secretariat expressed concern about the potential replication of governance processes, adding bureaucratic layers onto existing ones and creating new expenditures during a period of government restraint. In the end, the two levels of government made the unilateral decision to downgrade the MRP to a marine advisory committee, with a limited function of providing advice and recommendations to government on policies, processes, and strategic matters associated with new or existing activities. The MAC continued to operate as an advisory committee until June 2017, when Fisheries and Oceans Canada and the New Brunswick Department of Fisheries and Aquaculture effectively dismantled it (in letter provided by a key informant: Letter to Southwest New Brunswick Marine Advisory Committee, circulated 11 July 2017 to members of the Southwest New Brunswick Marine Advisory Committee by the Regional Director of Ecosystem Management Branch, Fisheries and Oceans Canada Maritimes Region, and the Provincial Director of Fisheries and Aquaculture Division, New Brunswick Department of Agriculture, Aquaculture and Fisheries). 
Table 1. Proposed institutional indicators from the Canadian Fisheries Research Network sustainability framework based on this study's findings.

\begin{tabular}{|c|c|c|}
\hline Goal & Indicators in southwest New Brunswick & Benefit of indicator \\
\hline \multicolumn{3}{|c|}{ Inclusivity: inclusive processes that support participation } \\
\hline \multirow{2}{*}{\multicolumn{2}{|c|}{ All stakeholders at the table }} & $\begin{array}{l}\text { - Stakeholders can influence problem articulation, problem } \\
\text { solving and decision-making }\end{array}$ \\
\hline & & $\begin{array}{l}\text { - Promotes continuous monitoring and assessment for } \\
\text { identification of risks }\end{array}$ \\
\hline & Type of stakeholder participation & - Signals how participation might be hindered or enabled \\
\hline \multicolumn{3}{|c|}{ Co-operation: best efforts are made to address conflicts between stakeholders } \\
\hline & Commitment to conflict resolution & $\begin{array}{l}\text { - Sources of conflict openly aired } \\
\text { - Neutralization of power dynamics }\end{array}$ \\
\hline & Development of community values criteria & $\begin{array}{l}\text { - Full suite of local values taken into consideration in } \\
\text { regional planning for resource use }\end{array}$ \\
\hline & Inclusion of local knowledge & - Improved problem solving \\
\hline \multicolumn{3}{|c|}{ Accountability: explicit consideration of responsibility for actions, decisions, and outcomes } \\
\hline & $\begin{array}{l}\text { Roles and responsibilities of stakeholders are } \\
\text { documented and understood by their } \\
\text { constituencies }\end{array}$ & - A clear line of responsibility \\
\hline \multicolumn{2}{|r|}{$\begin{array}{l}\text { Diverse stakeholders report back regularly to their } \\
\text { constituency }\end{array}$} & $\begin{array}{l}\text { - Those affected by planning decisions are informed about } \\
\text { how those decisions were taken and based on what criteria } \\
\text { - Trade-offs between values are more explicit and visible to } \\
\text { stakeholders }\end{array}$ \\
\hline
\end{tabular}

Transparency: open and transparent policies, procedures, decisions, and supporting documentation Projects assessed based on a widely disseminated set of community values

- Proponents and government regulators have a clear set of parameters to obtain a social license

Resources: funding and other support is adequate and reliable Financial support available for meetings, GIS mapping, community outreach, website development

- Long-term commitment and support to focus on coastal issues in a comprehensive, systematic, and coordinated way

- The planning group and wider public have the required information to answer specific planning questions
It is important to point out that the MRP/MAC was just one of many efforts by stakeholders in southwest New Brunswick to find resolutions to problems. Stakeholders involved with the MRP/ MAC were and continue to be involved in multiple strategic approaches to addressing issues in the marine environment, including court cases, reaching out to the media, direct representation to government, coalitions, protests, and working groups (e.g., CBC News 2012, Environment Canada 2013; Fundy North Fishermen's Association ghost gear retrieval: http://www. fundynorth.org/lost-at-sea-a-ghost-gear-retrieval-manual-2/). The MRP/MAC was noteworthy, however, as it institutionalized a comanagement initiative.

\section{THE MARINE RESOURCEPLANNING INITIATIVE/ MARINE ADVISORY COMMITTEE AND INSTITUTIONAL INNOVATION}

The MRP/MAC as an institution for adaptive comanagement illustrates several unique features around the neglected governance issues affecting sustainability, including inclusivity, cooperation, resource requirements, transparency, and accountability (Table 1). In terms of inclusivity, informants reported that diversity was well represented in the group and that this diverse group was successfully integrated into a working committee, despite past conflicts. This situation allowed for increased mutual understanding because conflicts and differing perspectives were aired around the table.

Cooperation was demonstrated through the development of the MRP, which was initially established to deal with conflict between actors in the Bay of Fundy who have a diversity of interests and values. The provincial and federal governments intervened and brought marine users together to address power relationships between actors. They sought to create a "power-neutral forum" in which actors were given equal time to speak and information was shared among all user groups. Accordingly, the power of all user groups at the table was expanded, rather than allowing one group to dominate at the expense of others (as in Coleman 2000, Pirie 2000). The objective was to resolve disputes rather than to 
avoid them, which was important because conflict between marine users was hindering both governance and management of the planning area. Cooperation was also illustrated in the collective approach to the development of the CVC. Informants stated that although social conflict was the catalyst for the creation of the MRP/MAC, the vision was to work together to develop a management plan for the region. An integral part of that exercise was consultation with coastal communities to establish what they valued about the marine environment. Using a bottom-up approach (Beckley et al. 2002, Reed et al. 2006), the MRP/MAC was able to have people articulate and then share with the broader community their most basic values. The $\mathrm{CVC}$ represents a unique snapshot of a broad array of community values, including a surprising level of support for the protection of Indigenous rights.

Transparency was enhanced by the use of such local community values in marine resource planning. In particular, when new projects were approved by government, informants argued that such approval would have to be justified when it deviated from local values. The CVC presented this suite of values in a transparent and simple manner. In addition, the MRP/MAC provided the forum for open dialogue about how the community values and objectives would need to be considered in decisionmaking processes and planning exercises. This requirement placed local values at the centre of political discussions. The process was successful to the extent that the CVC focused on four dimensions: ecological, cultural, social, and economic, with sixteen individual values $^{[1]}$ identified and later confirmed in a second round of community consultation.

Both the inclusivity of membership and the cooperation that MRP members demonstrated should, in turn, have supported a high level of accountability for the group as it reported back to their diverse constituencies.

The MRP also demonstrated innovative adaptive comanagement in terms of the resources initially allocated to support the planning group; significant financial and technical support were originally provided by the two levels of government. MRP meetings were held 10 times a year, with travel support for participants, and the Secretariat arranged technical support, including GIS mapping of the planning area, community outreach through survey development and distribution, website development, and materials. A technical subcommittee was also assembled to analyze and present the resulting CVC data (MRPP Committee 2005) in the form of a simple and clear table. Other expertise was assembled to attempt to operationalize the CVC.

\section{PROBLEMS EXPERIENCED BY THE MARINE RESOURCE PLANNING INITIATIVE/MARINE ADVISORY COMMITTEE}

Although the MRP/MAC incorporates adaptive comanagement and governance features highlighted as best practice by the CFRN sustainability framework, it also experienced challenges that provide lessons for the framework specifically and the adaptive comanagement literature more generally. In terms of inclusivity, for example, problems arose when the Government Secretariat tried to control who was admitted as a member of the MRP. In one case, a member of the Secretariat tried to block the appointment of a representative from an environmental nongovernmental organization. Although that person was admitted to the MRP in the end, it was clear that the Government Secretariat did not solely operate as technical support but attempted to control membership and agendas for meetings. Informants stated, for example, that they had difficulty getting some topics placed on the agenda for discussion. A more serious problem was that members of the initial planning group, including members of the Government Secretariat, were to act in a personal capacity as experts and thus to "take their hats off at the door" when they came to meetings. This "hats off" practice continued up to the final phase of the process, and members reported that this seriously compromised their ability to represent their stakeholder groups or to account for decisions taken by the group. This, in turn, affected transparency and accountability over time.

Maintaining cooperation over the lifetime of the MRP/MAC was also a problem. Because the MRP was downgraded to an advisory group, it became clear that the MAC would not review specific individual applications for marine planning unless the government requested it or it was agreed upon by both the MAC and the Secretariat (SNBMAC 2013). Cooperation was also difficult to maintain because resources declined sharply over the life of the MRP/MAC. Ten meetings per year was reduced to three, and plans for proactive community outreach were abandoned. The nongovernment members of the MRP/MAC reported that the rationale provided by government for the ultimate change in mandate was a reluctance by government to hand over power, but that other justifications included lack of government financial and human resources to meet the original objectives.

Further, informants reported that the CVC was never formally applied toward planning or management ends, citing two reasons. First, creating a hierarchy out of the values on the CVC turned out to be a difficult and time-consuming subjective process: "If there is a statement that comes out of the Marine Protected Area [for example], how does that statement fit with the CVC and [how to] apply that statement to each of the criteria... We tried to go through that process and it didn't work because if you had a simple statement that said this is important for these reasons, you might agree with it, but the person beside you has a different view of things," (Interview 6, 28 November 2013). Second, after the government decision to change the mandate, it was clear that the MAC would be restricted to providing advice on policies, in which case it was unnecessary to operationalize the CVC. Although the CVC was a step in the right direction, ultimately, the MAC was unable to address risk and conflict in the way that participants had expected.

One gap in the CVC was the lack of institutional values. When asked about this gap, informants stated that it was done deliberately to avoid biases in politics. They also suggested that it might be the result of the composition of the technical subcommittee, who aggregated the information from the consultations. That group was principally composed of ecologists, with only one social scientist. If only one person explicitly addressing social and institutional issues is invited to participate, institutional values are likely to remain weak, or in the CVC case, be absent altogether (Parlee 2016, see also Bostrom 2012, Vifell and Soneryd 2012). Without explicit attention to institutional values, improvements to governance such as conflict resolution, transparency, and accountability could be traded off 
unintentionally in favor of the ecological, social, cultural, and economic dimensions. We argue that the absence of an institutional category in the CVC had unanticipated consequences for the MRP/MAC. This finding led to support for arguments that the CFRN framework had to include clear and important indicators for governance.

\section{INSTITUTIONAL PROBLEMS}

The lack of institutional considerations in the CVC contributed to three major problems with implications for the CFRN framework (see Table 1). The first problem was the approach to dealing with conflict. Along with other respondents, the federal and provincial government respondents all agreed that the MRP/ MAC was specifically developed to address conflict. In contrast, informants stated that after the MAC was constituted solely as an advisory committee, it was no longer considered an appropriate venue for dispute resolution. Despite this, the MAC appears to have addressed some contentious issues. Relying on "communicative rationality" (Habermas 1987), the MAC discussed and developed recommendations for government on several topics that caused open conflict in the past, including infectious diseases in salmon aquaculture, marine protected areas, and marine debris. These processes included collaboration and communication between MRP/MAC members and members of the broader community who had authority and jurisdiction on the issue, including the use of local knowledge. The source of the discontinuity between the stated objective to resolve conflict and how, in fact, the MAC has reduced conflict could be the reluctance by both the federal and provincial government to commit resources and yield power over conflict resolution. Arguably, the governments were trying to suppress nonconsensual forms of conflict in favor of rational discourse, cooperation, and consensus. However, there is a danger that this approach will stifle dissent and create resistance, struggle, contestation, and exclusion (see Nader 1997, 2001, Mattei and Nader 2008). If dissent is too tightly repressed, it will find another outlet.

The second problem was the "hats off" policy whereby MAC members sat as individuals with knowledge or expertise in a specific area rather than as representatives of their stakeholder group. Informants argued that this practice did help to reduce conflict because they were not bound by organizational policy and did not have to sacrifice personal values in favor of group values, but could exercise personal judgement. This ultimately enabled people to engage in "constructive controversy" and to "separate people from the problem" (Fisher et al. 1991, Johnson et al. 2000). The literature on conflict resolution and adaptive comanagement, however, advocates representative participation because it promotes accountability (see Pinkerton 1994, Carlsson and Berkes 2005, Susskind 2006, Jentoft et al. 2009, Berkes 2010), and informants did raise concerns about participation, accountability, and transparency. Specifically, they suggested that MAC members were not obligated to communicate with "constituencies" and this created problems for external accountability (as in Keohane 2002). MAC members had widely diverging mechanisms for deciding how their members would receive feedback. Because they were not representatives, it was difficult for their constituencies and the broader public to disentangle the lines of participation, consultation, and accountability (as in Swyngedouw 2005). This accountability dilemma was exacerbated by the fact that the MAC did not receive support for its communication plan from the Government Secretariat, so that MAC members did not have a mechanism to satisfy individuals who wanted to learn about the decisionmaking process.

The third problem was the role of government at the table. According to federal policy and legislation, integrated management is supposed to be driven by Fisheries and Oceans Canada in collaboration with others (Fisheries and Oceans Canada 2005, Oceans Act S.C. 1996, c. 31). A key consideration is inclusiveness, which refers to opportunities available for stakeholders to influence problem articulation, problem solving, and decision making (Lockwood et al. 2010, also see Folke et al. 2005, Hughes et al. 2005, Armitage et al. 2009, Linke and Jentoft 2014). The role of government at the MAC table was understood by informants to be both procedural and substantive, and the literature states that this is assumed to be a neutral role (Hallström and Boström 2010). However, because the Weberian bureaucratic framework and associated top-down power structure continues as the primary approach to governance in Canada, the "hats off" policy could not apply to government members. Government participants, nonetheless, were able to assist MAC objectives in two ways: they could promote MAC recommendations within other agencies and governments (e.g., Regional Committees on Coastal and Oceans Management), and they could report back to the MAC about how recommendations were being addressed. These Regional Committees are the senior executive forum for federal and provincial governments to provide oversight, coordination, and direction to planning and management processes related to integrated coastal and oceans management (Fisheries and Oceans Canada 2011). However, "hats on" for government members was also a hindrance, as was demonstrated when the Government Secretariat attempted to block an environmental stakeholder from participating. Because this stakeholder appeared to promote open contestation (as in Flyvbjerg 1998:226, also see Takeda and Røpke 2010), it was possible to argue that he/she did not meet the criteria of constructive participation. However, the incident indicated how Government Secretariat members were not able to "take their hats off" and "separate people from the problem," and this, in turn, influenced who could participate and how. "Hats on" by government members also affected agenda setting.

Thus, in terms of the framework under development by the CFRN, this case study has important governance lessons to offer in terms of how governance institutions ought to be incorporated to protect and enhance inclusivity, cooperation, accountability, transparency, and resource allocation to innovative institutions (see Table 1).

\section{LESSONS FOR ADAPTIVE COMANAGEMENT}

We analyzed the development of the MRP/MAC as an innovative institution that was assembled in the context of growing interest in organizations for adaptive comanagement. In theory, innovative institutions for adaptive comanagement can help to resolve wicked problems because they can integrate different knowledge systems, assess and monitor human environmental interactions, and resolve conflict (Olsson et al. 2004, Folke et al. 2005, Hughes et al. 2005, Lemos and Agrawal 2006, Kearney et al. 2007, Armitage et al. 2009, Jentoft and Chuenpagdee 2009, Lockwood et al. 2010, Jentoft 2011, Linke and Jentoft 2014). We 
demonstrate that combining local and traditional knowledge systems with natural and social scientific knowledge to deal with issues requires inclusiveness, which refers to chances for stakeholders to engage in and influence problem articulation, problem solving, and decision making through collaboration and cooperation. Each of these different knowledge types is influenced by values. Values can structure governance and management because they enable governors to assess where the marine environment is, where it should be, and what means can be used to get it there. However, values are often concealed, and because they are diverse and complex, they are open to conflict. Values can only become the basis for decision making in governance and management if they are articulated, endorsed, and adjudicated by stakeholders (Sarewitz 2004, Bavinck et al. 2005, Glavovic 2016). An integral part of this process is the bridging of different knowledge types, values, and dimensions of sustainability (Folke et al. 2005). Successful management also requires continuous monitoring and assessment because it can identify uncertainty and risk associated with complex socialecological systems and allow managers to take the proper steps to reduce, mitigate, or control consequences arising from risk and uncertainty, and to resolve conflicts (Folke et al. 2005, Klinke and Renn 2012). Assessments and monitoring are inherently value driven because the question as to whether changes in the marine environment are sustainable is principally a human value judgement. To understand trade-offs made among ecological, social, economic, and institutional values, as well as the impact of decisions on various valued outcomes, a comprehensive suite of ecological, social, economic, and institutional (i.e., governance) values and indicators is necessary (Dietz et al. 2003, see also Bavinck et al. 2005, Keen and Mahanty 2006, Charles et al. 2010). Conflict resolution procedures are also important, such as neutralizing power dynamics among stakeholders, deliberation, argumentation, and negotiation of stakeholders' norms and values (Folke et al. 2005, Armitage et al. 2009, Jentoft and Chuenpagdee 2009, Davies and White 2012, Glavovic 2015, 2016). We illustrate that these three key characteristics of adaptive comanagement, i.e., the integration of different knowledge systems, the assessment and monitoring of social-ecological systems, and conflict resolution, suggest appropriate conduct for how to achieve the resolution of wicked problems and sustainability of the marine environment.

\section{CONCLUSION}

The literature on adaptive comanagement provided a theoretical lens for this case study. We suggest, however, that that body of work is normative in orientation and refers to ideal states. It is important to understand how people internalize ideas about governing and management, and how it influences real behavior. To help explain how this happens, the critical lens of poststructuralist scholarship as described by Mather et al. (2017) was brought in to this case study as an innovative institution for adaptive comanagement. From the perspective of this critical scholarship, we can offer lessons for improving the several weaknesses of innovative institutions for adaptive comanagement such as the MRP/MAC. First, such innovative institutions need explicitly to recognize and commit to a conflict resolution measure, otherwise they will miss opportunities to deal with stakeholder conflicts that may be harmful to subsequent good governance process. Second, such institutions need to allow for the possibility that overt forms of resistance such as protests, blockages, or demonstrations by actors that are involved in conflict might be an effective way forward. If contestation is repressed, it could find a potentially damaging channel for expression. Third, if such institutions are to accept participation without representation (i.e., recognize some form of "hats off at the door" policy), it is essential to evaluate the resources and support required to develop and implement a communication plan to further transparency and accountability to constituents. Fourth, explicit consideration must be given to the fact that government members of alternative governance structures cannot easily "take their hats off." Both the positive and negative implications of this fact need to be considered and evaluated as it relates to their role at the table. Fifth, institutional or governance values need to be explicit in any comanagement initiative such as the MRP/MAC and, thus, represented in measurement tools as demonstrated in the CFRN framework. Without institutional values, measures of good governance such as conflict resolution, transparency, and accountability cannot be assessed, or worse, may be traded off to achieve government or other agendas (e.g., industry). Sixth, such institutions require some measure of the extent to which alternative or participatory forms of governance have real powers to address trade-offs among the diverse values and to provide advice and recommendations to government with full knowledge of the anticipated consequences.

The case study of the MRP/MAC also offers lessons for advancing the theoretical and empirical literature on adaptive comanagement. We argue that there are two significant gaps in the adaptive comanagement literature and, perhaps, also in the literature on participatory governance more broadly. First, the literature favors a Habermasian "communicative rationality" approach to dealing with conflict, as opposed to a Foucauldian "nonconsensual" approach. This case study and the literature on governmentality demonstrate that although the Habermasian approach can resolve conflict in some circumstances, it can also become a threat to governance processes because the onedimensional approach suppresses dissent rather than legitimizes it. Second, the adaptive comanagement literature views nonrepresentation as a shortcoming in governance processes. The literature assumes that innovative institutions such as the MAC inherently promote representativeness, which results in accountability and transparency. In contrast, this case study, along with the literature on conflict resolution, raises the argument that there are advantages of nonrepresentation. Members of adaptive comanagement institutions are not always representative, and accountability and transparency are not inherent outcomes of participatory processes. This case study indicates that innovative institutions for adaptive comanagement can at once offer greater promise of democracy and fundamentally restructure the parameters of political democracy (Swyngedouw 2005). Arguably, the literature on adaptive comanagement has failed to consider this Janus-faced nature of the role of conflict in both enabling and hindering innovative institutions. If we are going to build innovative institutions to enhance sustainability, the adaptive comanagement literature must identify and explore these contradictory tendencies and determine the implications of it on the democratic content of participatory processes. 
Finally, the case study of the MAC offers lessons for the institutional indicators in the CFRN framework through deeper consideration of challenges in creating institutions of good governance. This case study was both informed by and informed the development of the CFRN framework. In particular, it contributed to five governance measures from the CFRN framework, including cooperation, resources, transparency, accountability, and inclusivity. Weaknesses were identified in the measure for transparency and the measure for inclusiveness. The framework allows users to assess whether there are mechanisms in place to ensure transparency and accountability. However, it focuses on the "what" question and is missing the "how" question. Therefore, to strengthen measures for transparency, we recommend that an indicator be added to examine how transparency and accountability criteria emerge, in addition to the shortcomings or assets of specific practices. Although the framework does contain measures that enable users to assess whether processes encourage inclusivity and participation, the measures do not capture the complexity of stakeholder participation such as that illustrated in the MRP/MAC under the "hats off" policy. To improve measures for inclusivity, we suggest that an indicator of characteristics of representation be added, prompting users to examine how stakeholders are represented and the extent to which it influences their ability to participate.

[1] Values in the CVC were expressed through questions that addressed four categories: ecological, cultural, social, and economic. Ecological: Will the proposal alter the natural and physical environment such as noise or light levels, sedimentation, water quality, or circulation? Will it use hazardous material, risk of invasive species, species transfer, or repetitive use of materials known to influence enrichment and eutrophication? Cultural: Will the proposal affect Indigenous traditions such as ceremonial harvest? Will it affect a marine area or site of known heritage or archeological importance? Social: Will the project provide equitable access to shoreline and marine space for social activities? Will it contribute to community health and human growth? Economic: Will the project affect existing local economic livelihoods or future opportunities or activities? Is it financially self-sufficient and does it demonstrate sustainability?

Responses to this article can be read online at: http://www.ecologyandsociety.org/issues/responses. php/10334

\footnotetext{
Acknowledgments:

This work was supported by the Social Science and Humanities Research Council of Canada under the Doctoral Fellowship Program. The authors also acknowledge the Natural Science and Engineering Research Council of Canada (NSERC) Canadian Fisheries Research Network and the University of New Brunswick for support. We thank the interview participants for sharing their insights with us and for their time. We also thank our reviewers, who provided greatly appreciated constructive comments and feedback.
}

\section{LITERATURE CITED}

Armitage, D. R., R. Plummer, F. Berkes, R. I. Arthur, A. T. Charles, I. J. Davidson-Hunt, A. P. Diduck, N. C. Doubleday, D. S. Johnson, M. Marschke, P. McConney, E. W. Pinkerton, and E. K. Wollenberg. 2009. Adaptive co-management for socialecological complexity. Frontiers in Ecology and the Environment 7(2):95-102. http://dx.doi.org/10.1890/070089

Auditor General of Canada. 2013. Progress in implementing integrated management of Canada's oceans. Office of the Auditor General of Canada, Ottawa, Canada. [online] URL: http://www. oag-bvg.gc.ca/internet/English/pet 354 e 39108.html

Barnett, A. J., M. G. Wiber, M. P. Rooney, and D. G. Curtis Maillet. 2016. The role of public participation GIS (PPGIS) and fishermen's perceptions of risk in marine debris mitigation in the Bay of Fundy, Canada. Ocean and Coastal Management 133:85-94. http://dx.doi.org/10.1016/j.ocecoaman.2016.09.002

Bavinck, M., R. Chuenpagdee, M. Diallo, P. van der Heijden, J. Kooiman, R. Mahon, and S. Williams. 2005. Interactive fisheries governance: a guide to better practice. Eburon, Delft, The Netherlands.

Beckley, T., J. Parkins, and R. Stedman. 2002. Indicators of forestdependent community sustainability: the evolution of research. Forestry Chronicle 78(5):626-636. http://dx.doi.org/10.5558/ tfc78626-5

Begg, G. A., R. L. Stephenson, T. Ward, B. M. Gillanders, and T. Smith. 2015. Practical steps to implementation of integrated marine management: report of a workshop, 13-15 April 2015. SARDI Publication F2015/000465-1, SARDI Research Report Series 848. Final Report for the Spencer Gulf Ecosystem and Development Initiative and the Fisheries Research and Development Corporation. South Australian Research and Development Institute, Adelaide, Australia. [online] URL: http:// www.pir.sa.gov.au/ data/assets/pdf file/0019/256303/

Practical steps to implementation of integrated marine management. pdf

Berkes, F. 2010. Devolution of environment and resources governance: trends and future. Environmental Conservation 37 (4):489-500. http://dx.doi.org/10.1017/S037689291000072X

Boström, M. 2012. A missing pillar? Challenges in theorizing and practicing social sustainability: introduction to the special issue. Sustainability: Science, Practice, and Policy 8(1):3-14. https://doi. org/10.1080/15487733.2012.11908080

Carlsson, L., and F. Berkes. 2005. Co-management: concepts and methodological implications. Journal of Environmental Management 75(1):65-76. http://dx.doi.org/10.1016/j.jenvman.2004.11.008

CBC News. 2012. Scientists fight to save library from Federal cuts. CBC News 27 August 2012. [online] URL: http://www.cbc.ca/ news/canada/new-brunswick/scientists-fight-to-save-library-fromfederal-cuts-1.1266116

Charles, A., M. Wiber, K. Bigney, D. Curtis, L. Wilson, R. Angus, J. Kearney, M. Landry, M. Recchia, H. Saulnier, and C. White. 2010. Integrated management: a coastal community perspective. Horizons 10(4):26-34. [online] URL: http://smu-facweb.smu.ca/ charles/PDFS 2005/094.pdf 
Charmaz, K. 2006. Constructing grounded theory: a practical guide through qualitative analysis. Sage, Thousand Oaks, California, USA.

Coleman, P. T. 2000. Power and conflict. Pages 108-130 in M. Deutsch and P. T. Coleman, editors. The handbook of conflict resolution: theory and practice. Jossey-Bass, San Francisco, California, USA.

Dahl, A. L. 2012. Achievements and gaps in indicators for sustainability. Ecological Indicators 17:14-19. https://doi. org/10.1016/j.ecolind.2011.04.032

Davies, A. L., and R. M. White. 2012. Collaboration in natural resource governance: reconciling stakeholder expectations in deer management in Scotland. Journal of Environmental Management 112:160-169. http://dx.doi.org/10.1016/j.jenvman.2012.07.032

Dietz, T., E. Ostrom, and P. C. Stern. 2003. The struggle to govern the commons. Science 302(5652):1907-1912. http://dx.doi. org/10.1126/science.1091015

Environment Canada. 2013. Kelly Cove Salmon Ltd. ordered to pay \$500,000 for Federal Fisheries Act violations. News release. Environment and Climate Change Canada, Ottawa, Canada. [online] URL: http://ec.gc.ca/default.asp?lang=En\&n=976258C$\underline{6-1 \& n e w s=4487 \mathrm{~A} 585-\mathrm{B} 7 \mathrm{EE}-4596-\mathrm{BA} 5 \mathrm{~B}-\mathrm{CEE} 27498 \mathrm{E} 6 \mathrm{EF}}$

Fisher, R., W. Ury, and B. Patton. 1991. Getting to yes: negotiating agreement without giving in. Second edition. Houghton Mifflin, Boston, Massachusetts, USA.

Fisheries and Oceans Canada. 2002. Canada's Oceans Strategy: our oceans, our future. Fisheries and Oceans Canada, Ottawa, Canada. [online] URL: http://waves-vagues.dfo-mpo.gc.ca/ Library/264675.pdf

Fisheries and Oceans Canada. 2005. Canada's Oceans Action Plan: for present and future generations. Fisheries and Oceans Canada, Ottawa, Canada. [online] URL: http://waves-vagues. dfo-mpo.gc.ca/Library/315255e.pdf

Fisheries and Oceans Canada. 2011. Memorandum of understanding respecting coastal and oceans management in Nova Scotia. Fisheries and Oceans Canada, Ottawa, Canada. [online] URL: http://www.dfo-mpo.gc.ca/reports-rapports/MOU-eng.htm

Flyvbjerg, B. 1998. Habermas and Foucault: thinkers for civil society? British Journal of Sociology 49(2):210-232. http://dx.doi. org $/ 10.2307 / 591310$

Folke, C., T. Hahn, P. Olsson, and J. Norberg. 2005. Adaptive governance of social-ecological systems. Annual Review of Environment and Resources 30:441-473. http://dx.doi.org/10.1146/ annurev.energy.30.050504.144511

Glavovic, B. C. 2015. On the frontline in the Anthropocene: adapting to climate change through deliberative coastal governance. Pages 51-100 in B. C Glavovic, M. Kelly, R. Kay, and A. Travers, editors. Climate change and the coast: building resilient communities. CRC Press, Boca Raton, Florida, USA.

Glavovic, B. C. 2016. Towards deliberative coastal governance: insights from South Africa and the Mississippi Delta. Regional Environmental Change 16(2):353-365. http://dx.doi.org/10.1007/ s10113-014-0727-4
Habermas, J. 1987. The philosophical discourse of modernity. twelve lectures. MIT Press, Cambridge, Massachusetts, USA.

Hallström, K. T., and M. Boström. 2010. Transnational multistakeholder standardization: organizing fragile non-state authority. Edward Elgar, Cheltenham, UK.

Hughes, T. P., D. R. Bellwood, C. Folke, R. S. Steneck, and J. Wilson. 2005. New paradigms for supporting the resilience of marine ecosystems. Trends in Ecology and Evolution 20 (7):380-386. http://dx.doi.org/10.1016/j.tree.2005.03.022

Jentoft, S. 2011. Legal pluralism and the governability of fisheries and coastal systems. Journal of Legal Pluralism and Unofficial Law 43(64):149-172. http://dx.doi.org/10.1080/07329113.2011.10756673

Jentoft, S., M. Bavinck, D. Johnson, and K. Thomson. 2009. Fisheries co-management and legal pluralism: how an analytical problem becomes an institutional one. Human Organization 68 (1):27-38. http://dx.doi.org/10.17730/humo.68.1.h87q04245t63094r

Jentoft, S., and R. Chuenpagdee. 2009. Fisheries and coastal governance as a wicked problem. Marine Policy 33(4):553-560. http://dx.doi.org/10.1016/j.marpol.2008.12.002

Johnson, D. W., R. Johnson, and D. Tjosvold. 2000. Constructive controversy: the value of intellectual opposition. Pages 65-85 in M. Deutsch and P. T. Coleman, editors. The handbook of conflict resolution: theory and practice. Jossey-Bass, San Francisco, California, USA.

Kearney, J., F. Berkes., A. Charles, E. Pinkerton, and W. Wiber. 2007. The role of participatory governance and community-based management in integrated coastal and ocean management in Canada. Journal of Coastal Management 35(1):79-104. http://dx. doi.org/10.1080/10.1080/08920750600970511

Keen, M., and S. Mahanty. 2006. Learning in sustainable natural resource management: challenges and opportunities in the Pacific. Society and Natural Resources 19(6):497-513. http://dx. doi.org/10.1080/08941920600663896

Keohane, R. O. 2002. Global governance and democratic accountability. In D. Held and M. Koenig-Archibugi, editors. Taming globalization: frontiers of governance. Polity Press, Cambridge, UK.

Klinke, A., and O. Renn. 2012. Adaptive and integrative governance on risk and uncertainty. Journal of Risk Research 15 (3):273-292. https://doi.org/10.1080/13669877.2011.636838

Lemos, M. C., and A. Agrawal. 2006. Environmental governance. Annual Review of Environment and Resources 31:297-325. http:// dx.doi.org/10.1146/annurev.energy.31.042605.135621

Linke, S., and S. Jentoft. 2014. Exploring the phronetic dimension of stakeholders' knowledge in EU fisheries governance. Marine Policy 47:153-161. http://dx.doi.org/10.1016/j.marpol.2013.10.010

Lipton, P. 2000. A companion to the philosophy of science. Pages 184-193 in W. H. Newton-Smith, editor. A companion to the philosophy of science. Blackwell, Hoboken, New Jersey, USA.

Lockwood, M., J. Davidson, A. Curtis, E. Stratford, and R. Griffith. 2010. Governing principles for natural resource management. Society and Natural Resources 23(10):986-1001. https://doi.org/10.1080/08941920802178214 
Marine Resource Plan Development Steering Committee (MRPP Committee). 2009. The preferred future of the Bay: recommendations toward a community based plan for the management of marine activities and spaces in Southwest New Brunswick Bay of Fundy. MRPP Committee, Saint John, Canada. [online] URL: http://www.bofmrp.ca/home/images/uploads/ Preferred-Future-of-the-Bay-English-Version.doc

Marine Resource Planning Process Committee (MRPP Committee). 2005. Southwestern Bay of Fundy marine resource planning process initiative: phase 1 final report. MRPP Committee, Saint John, Canada. [online] URL: http://bofmrp.ca/home/index. php/site/reports1/

Mather, C., J. P. Johnsen, S. Sonvisen, A. Sridhar, and J. Stephen. 2017. Introduction to the themed issue - Poststructural approaches to fisheries. Maritime Studies 16:20. http://dx.doi. org/10.1186/s40152-017-0074-4

Mattei, U., and L. Nader. 2008. Plunder: when the rule of law is illegal. Blackwell, Malden, Massachusetts, USA. http://dx.doi. org/10.1002/9780470696552

Melzer, E. 1998. International review of integrated coastal zone management. Oceans Conservation Report Series. Department of Fisheries and Oceans, Ottawa, Canada. [online] URL: http:// www.dfo-mpo.gc.ca/Library/253987.pdf

Nader, L. 1997. Controlling processes: tracing the dynamic components of power. Current Anthropology 38(5):711-737. https://doi.org/10.1086/204663

Nader, L. 2001. Harmony coerced is freedom denied. Chronicle of Higher Education 47:B13-B16.

Olsson, P., C. Folke, and F. Berkes. 2004. Adaptive comanagement for building resilience in social-ecological systems. Environmental Management 34(1):75-90. https://doi.org/10.1007/s00267-003-0101-7

Parlee, C. E. 2016. Resolving conflict over risk management in the marine environment: strengthening governance institutions. Dissertation. University of New Brunswick, Fredericton, Canada. [online] URL: https://unbscholar.lib.unb.ca/islandora/ object/unbscholar\%3A7858/

Phyne, J. 1996. Along the coast and in the State: aquaculture and politics in Nova Scotia and New Brunswick. In C. Bailey, S. Jentoft, and P. Sinclair, editors. Aquaculture development: social dimensions of an emerging industry. Westview Press, Boulder, Colorado, USA.

Pinkerton, E. W. 1994. Local fisheries co-management: a review of international experiences and their implications for salmon management in British Columbia. Canadian Journal of Fisheries and Aquatic Sciences 51(10):2363-2378. http://dx.doi.org/10.1139/ $\underline{\text { f94-238 }}$

Pirie, A. J. 2000. Alternative dispute resolution: skills, science, and the law. Irwin Law, Toronto, Canada.

Reed, M. S., E. D. G. Fraser, and A. J. Dougill. 2006. An adaptive learning process for developing and applying sustainability indicators with local communities. Ecological Economics 59 (4):406-418. http://dx.doi.org/10.1016/j.ecolecon.2005.11.008
Sarewitz, D. 2004. How science makes environmental controversies worse. Environmental Science and Policy 7 (5):385-403. http://dx.doi.org/10.1016/j.envsci.2004.06.001

Southwest New Brunswick Marine Advisory Committee (SNBMAC). 2013. Consensus based advice/recommendations on marine debris. SNBMAC, Saint John, Canada. [online] URL: http://www.bofmrp.ca/home/images/uploads/MAC_Advice_Recommendations Marine Debris September 252013 Final 2.pdf

Stephenson, R. L., S. Paul, M. Wiber, E. Angel, A. Benson, A. Charles, O. Chouinard, M. Clemens, D. Edwards, P. Foley, L. Jennings, O. Jones, D. Lane, J. McIsaac, C. Mussells, B. Neis, B. Nordstrom, C. Parlee, E. Pinkerton, M. Saunders, K. Squires, and U. R. Sumaila. 2018a. Evaluating and implementing socialecological systems: a comprehensive approach to sustainable fisheries. Fish and Fisheries 19(5):853-873. https://doi. org/10.1111/faf.12296

Stephenson, R. L., M. Wiber, S. Paul, E. Angel, A. Benson, A. Charles, O. Chouinard, D. Edwards, P. Foley, D. Lane, J. McIsaac, B. Neis, C. Parlee, E. Pinkerton, M. Saunders, K. Squires, and R. U. Sumaila. 2018b. Integrating diverse objectives for sustainable fisheries in Canada. Canadian Journal of Fisheries and Aquatic Sciences, in press. https://doi.org/10.1139/cjfas-2017-0345

Susskind, L. 2006. Can public policy dispute resolution meet the challenges set by deliberative democracy? Dispute Resolution Magazine 12(2):5-6.

Swyngedouw, E. 2005. Governance innovation and the citizen: the Janus face of governance-beyond-the-State. Urban Studies 42 (11):1991-2006. http://dx.doi.org/10.1080/00420980500279869

Takeda, L., and I. Røpke. 2010. Power and contestation in collaborative ecosystem-based management: the case of Haida Gwaii. Ecological Economics 70:178-188. https://doi.org/10.1016/ j.ecolecon.2010.02.007

Vifell, A. C., and L. Soneryd. 2012. Organizing matters: how the "social dimension" gets lost in sustainability projects. Sustainable Development 20(1):18-27. https://doi.org/10.1002/sd.461

Wiber, M. G. 2014. Syncopated rhythms? Temporal patterns in natural resource management. Journal of Legal Pluralism and Unofficial Law 46(1):123-140. http://dx.doi.org/10.1080/073291$\underline{13.2014 .888906}$ 
Appendix 1 Evaluation Framework for Sustainable Fisheries, Version 2.1, Example Indicators and Attributes

DOMAIN: ECOLOGICAL

\begin{tabular}{|c|c|c|}
\hline DIMENSION & ELEMENT & INDICATOR \\
\hline \multirow[t]{3}{*}{ Productivity } & $\begin{array}{l}\text { Ecological Productivity: } \\
\text { Fluctuations of Species } \\
\text { and Population } \\
\text { Abundance }\end{array}$ & $\begin{array}{l}\text { - }[\text { Recruitment Dynamics] }]^{6} \text { description for [Resource } \\
\text { Demographic Category] }]^{2} \text { within a [Resource Geographic } \\
\text { Region] } \\
\text { - [Quantification] }]^{12} \text { of Fishing Mortality. } \\
\text { - [Quantification] }]^{12} \text { of Escapement and determine } \\
\text { relationship to [Recruitment Dynamics] }]^{6} \text {. }\end{array}$ \\
\hline & $\begin{array}{l}\text { Geographic Range: } \\
\text { Fluctuations of species } \\
\text { and population } \\
\text { geographic range. }\end{array}$ & $\begin{array}{l}\text { - }[\text { Index of Abundance }]^{4} \text { in a [Resource Geographic } \\
\left.\text { Region }]^{3} \text { during a [Time Period }\right]^{5} \\
\text { - }[\text { Status }]^{1} \text { of }[\text { Resource Demographic Category }]^{2} \text { within a } \\
{[\text { Resource Geographic Region }]^{3}}\end{array}$ \\
\hline & $\begin{array}{l}\text { Phenotypic \& Genetic } \\
\text { Diversity: Fluctuation of } \\
\text { species and population } \\
\text { phenotypic and genetic } \\
\text { diversity }\end{array}$ & 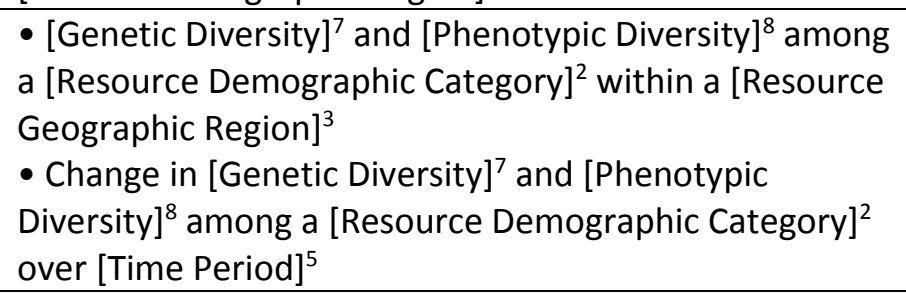 \\
\hline \multirow[t]{2}{*}{ Habitat } & $\begin{array}{l}\text { Substrate Quality: } \\
\text { Changes to benthic } \\
\text { geology and } \\
\text { geomorphology }\end{array}$ & 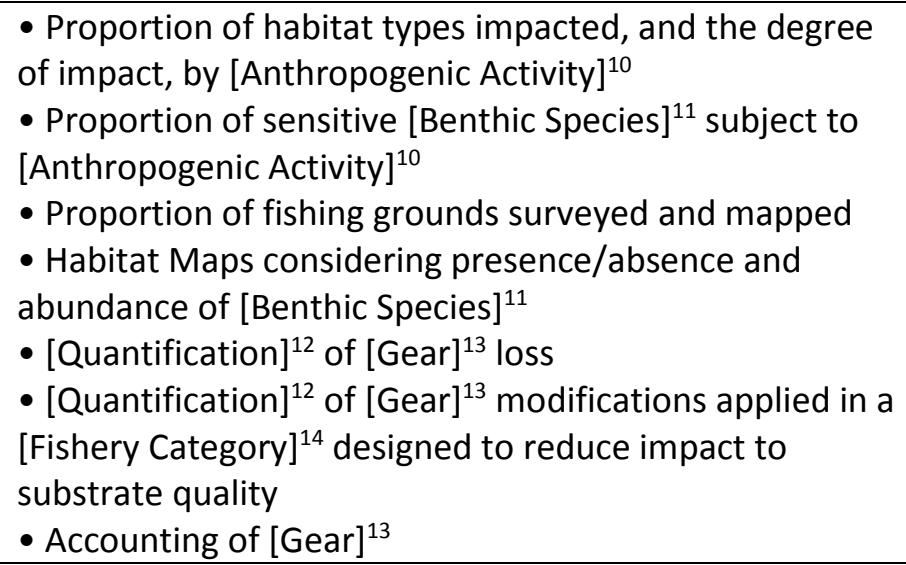 \\
\hline & $\begin{array}{l}\text { Water Quality: Changes } \\
\text { to water quality. }\end{array}$ & 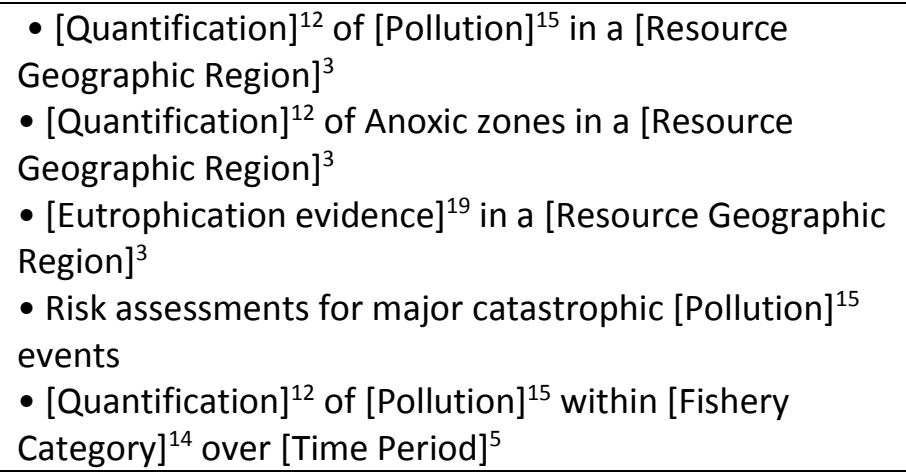 \\
\hline
\end{tabular}




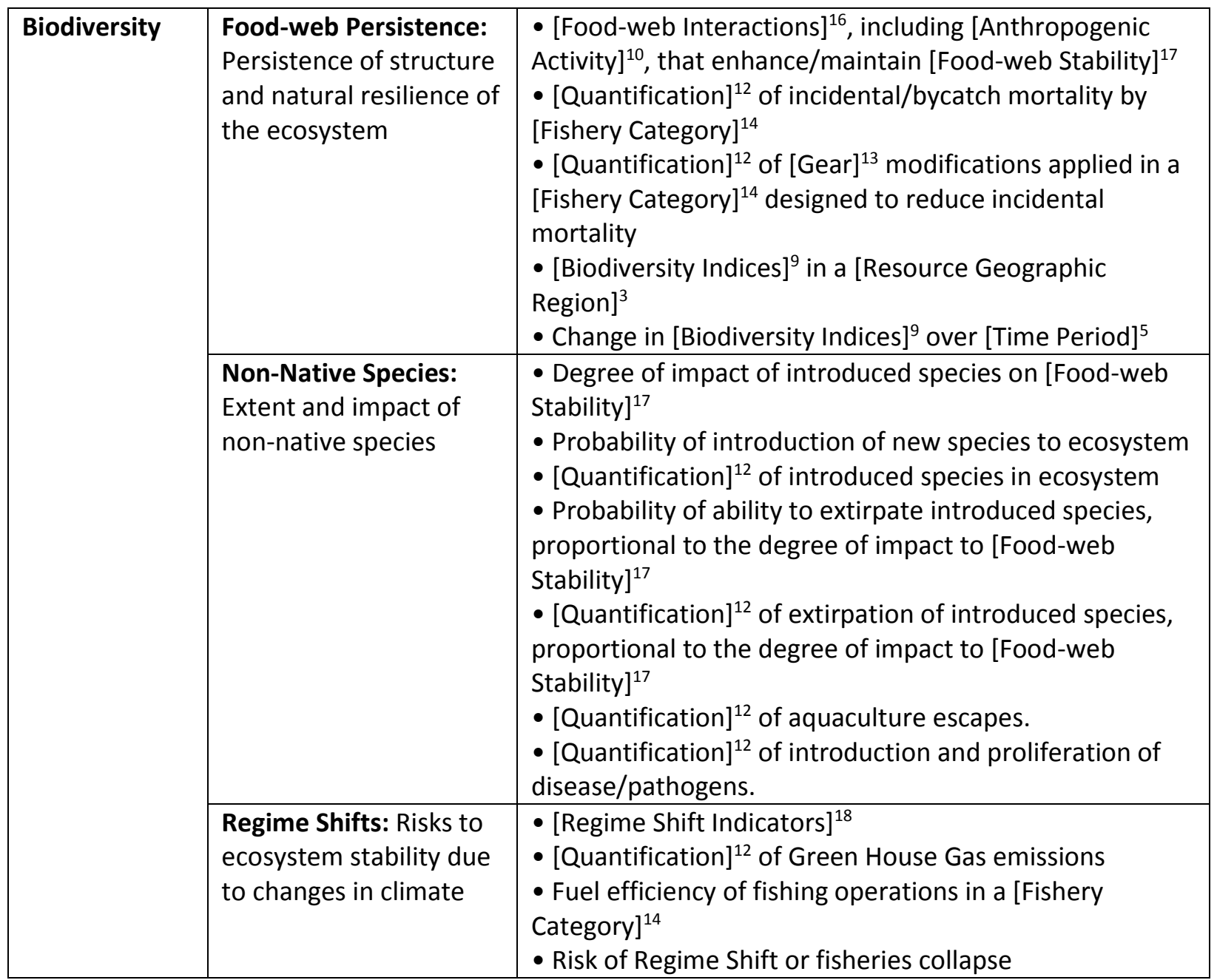

DOMAIN: COMMUNITY

\begin{tabular}{|c|c|c|}
\hline $\begin{array}{l}\text { Health and } \\
\text { well-being }\end{array}$ & $\begin{array}{l}\text { Basic needs: Fulfillment } \\
\text { of basic human needs }\end{array}$ & $\begin{array}{l}\text { - }\left[\text { Social Factor] }{ }^{20} \text { among [Human Population] }\right]^{21} \text { in } \\
\text { [Human Geographic Region] }^{22} \\
\text { - Proportion of [Human Population] }{ }^{21} \text { in [Human } \\
\text { Geographic Region] }{ }^{22} \text { below the poverty line } \\
\text { - Income disparity in [Human Geographic Region] }{ }^{22} \text { (e.g., } \\
\text { Gini coefficient, ratio of highest wage to average wage) } \\
\text { - Availability of affordable [Services] }{ }^{23} \text { to [Human } \\
\text { Population] }{ }^{21} \text { in [Human Geographic Region] }{ }^{22} \\
\text { - Ratio of [Services] }{ }^{23} \text { cost to gross adjusted disposable } \\
\text { income of the household } \\
\text { - Ranking of the quality of [Education] }{ }^{24} \text { at [Human } \\
\text { Geographic Region] }{ }^{22} \text { level }\end{array}$ \\
\hline
\end{tabular}




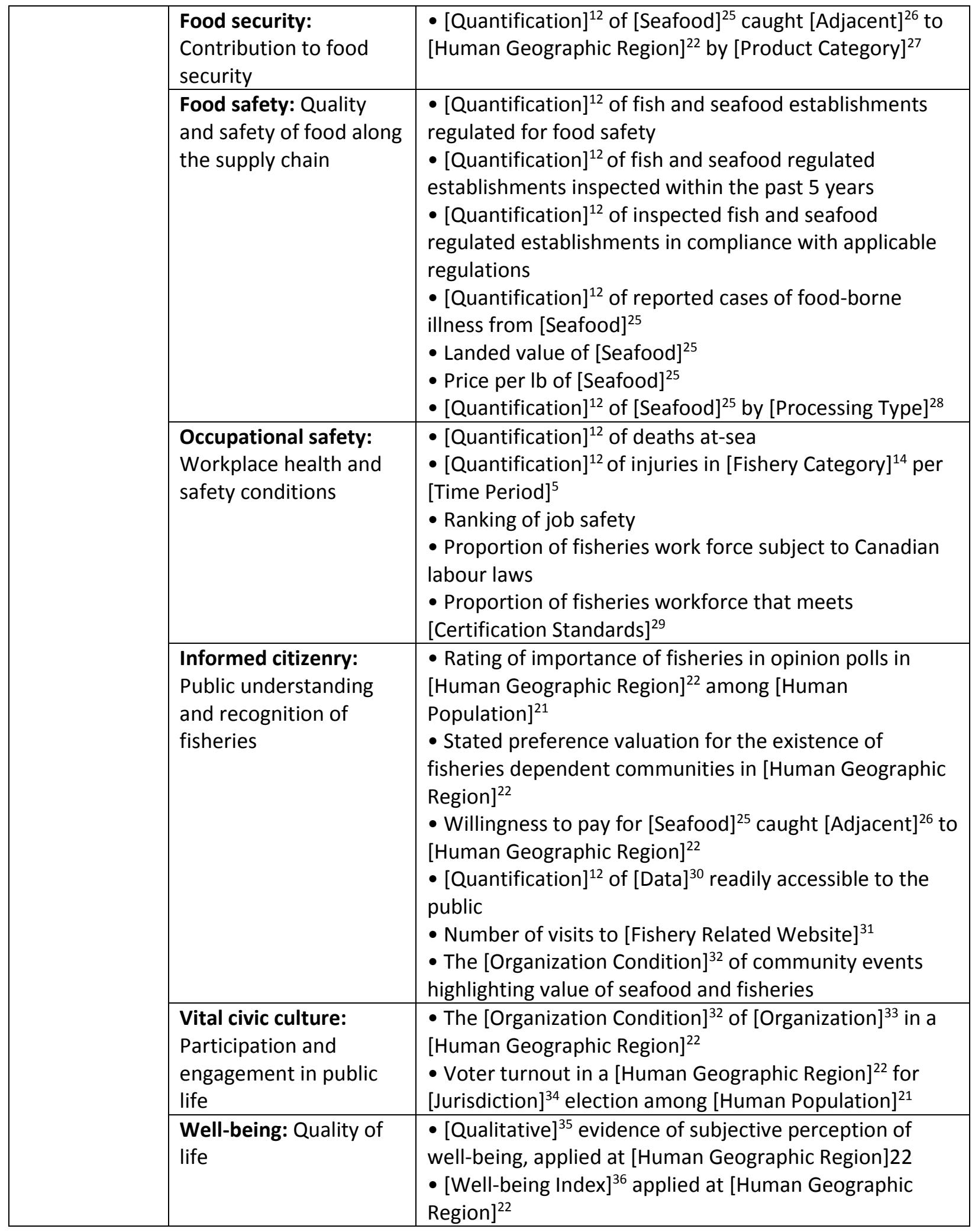




\begin{tabular}{|c|c|c|}
\hline \multirow[t]{5}{*}{$\begin{array}{l}\text { Equity and } \\
\text { Fairness }\end{array}$} & $\begin{array}{l}\text { Allocation: Fairness in } \\
\text { the allocation of } \\
\text { resource benefits }\end{array}$ & $\begin{array}{l}\text { - [Quantification] }{ }^{12} \text { of reallocations of [Resource } \\
\text { Demographic Category] }{ }^{2} \text { across [Stakeholder Group] } \\
\text { rights without [Compensation] } \\
\text { - Proportion of realized [Compensation] }{ }^{39} \text { relative to fair } \\
\text { market value of reallocated [Resource Demographic } \\
\text { Category] }{ }^{2} \text { across [Stakeholder Group] }{ }^{38} \text { rights } \\
\text { - Proportion of realized allocation relative to potential } \\
\text { allowed allocation } \\
\text { - Loss of income from reallocation of access rights by } \\
\text { [Economic Unit] }^{37} \text { in [Human Geographic Region] }{ }^{22} \\
\text { - [Quantification] }{ }^{12} \text { of [Seafood] }{ }^{25} \text { harvest across [Fishery } \\
\text { Category] }{ }^{14} \text { being contested by one or more [Stakeholder } \\
\text { Group] }]^{38}\end{array}$ \\
\hline & $\begin{array}{l}\text { Stability: Stability of } \\
\text { access to resource } \\
\text { benefits }\end{array}$ & 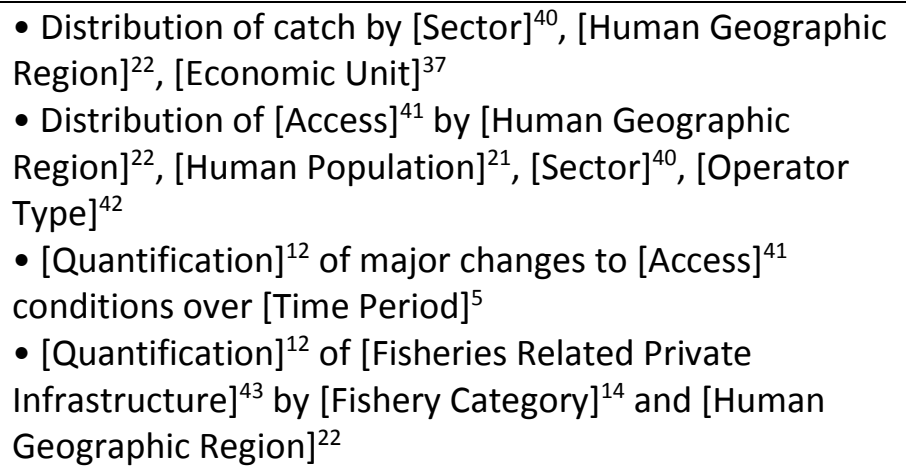 \\
\hline & $\begin{array}{l}\text { Costs } \& \text { Benefits: } \\
\text { Equitable distribution of } \\
\text { benefits and costs }\end{array}$ & 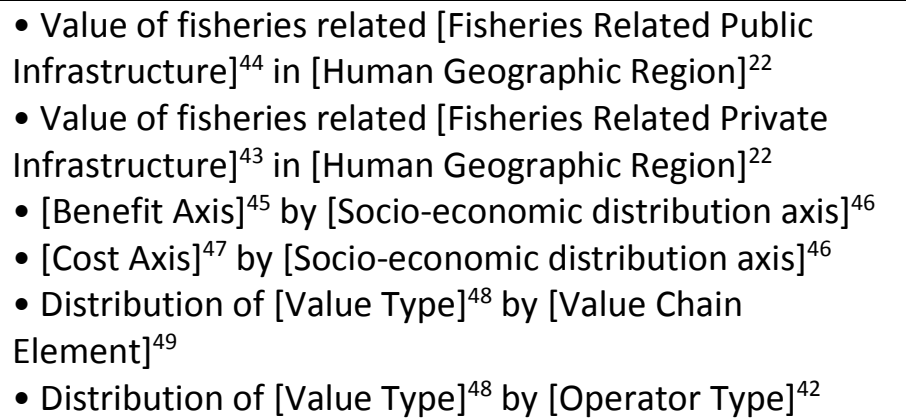 \\
\hline & $\begin{array}{l}\text { Risks \& Rewards: } \\
\text { Equitable distribution of } \\
\text { risks and rewards }\end{array}$ & - [Risk Axis] ${ }^{50}$ by [Socio-economic Distribution Axis] ${ }^{46}$ \\
\hline & $\begin{array}{l}\text { Livelihoods: } \\
\text { Sustainability of } \\
\text { livelihoods }\end{array}$ & $\begin{array}{l}\text { - [Livelihood Index }]^{51} \text { applied at [Human Geographic } \\
\text { Region] }{ }^{22} \\
\text { - Unemployment rate in fishery-dependent [Human } \\
\text { Geographic Region] }{ }^{22}\end{array}$ \\
\hline $\begin{array}{l}\text { Economic and } \\
\text { financial }\end{array}$ & $\begin{array}{l}\text { Human capital: } \\
\text { Development and } \\
\text { maintenance of human } \\
\text { capital }\end{array}$ & $\begin{array}{l}\text { - } \text { [Human Demographic Axis] }^{52} \text { by [Occupational Axis] } \\
\text { - [Quantification }]^{12} \text { of [Time Period]5 in the industry by } \\
\text { [Occupational Axis] }{ }^{53} \\
\text { - [Quantification] }]^{12} \text { of generations of fishing history of } \\
\text { current participants in the fishery }\end{array}$ \\
\hline
\end{tabular}




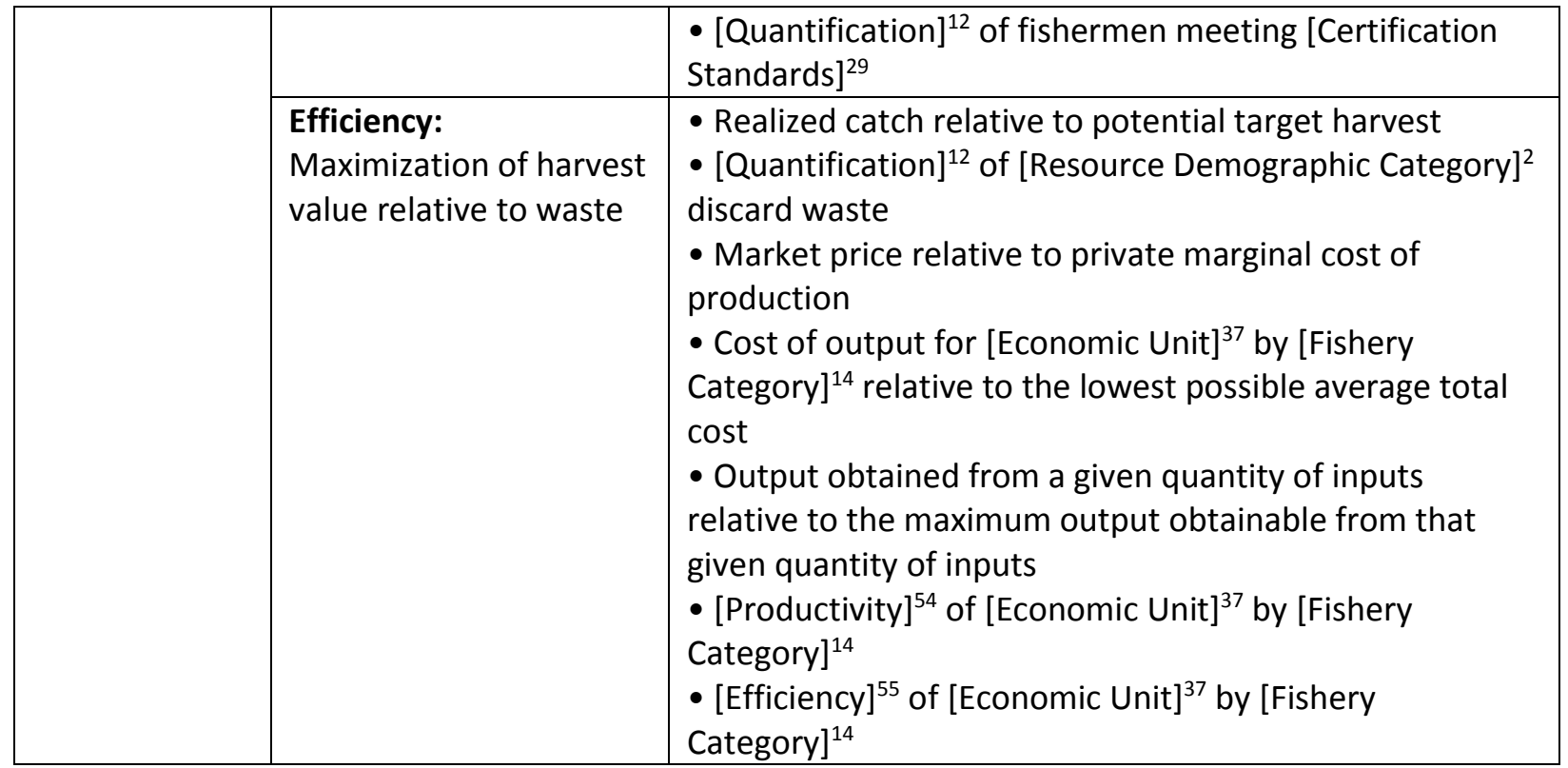

\section{DOMAIN: INSTITIONAL}

\begin{tabular}{|c|c|c|}
\hline \multirow[t]{3}{*}{ Structure } & $\begin{array}{l}\text { Rules: Legal, regulatory } \\
\text { and policy framework is } \\
\text { appropriate }\end{array}$ & 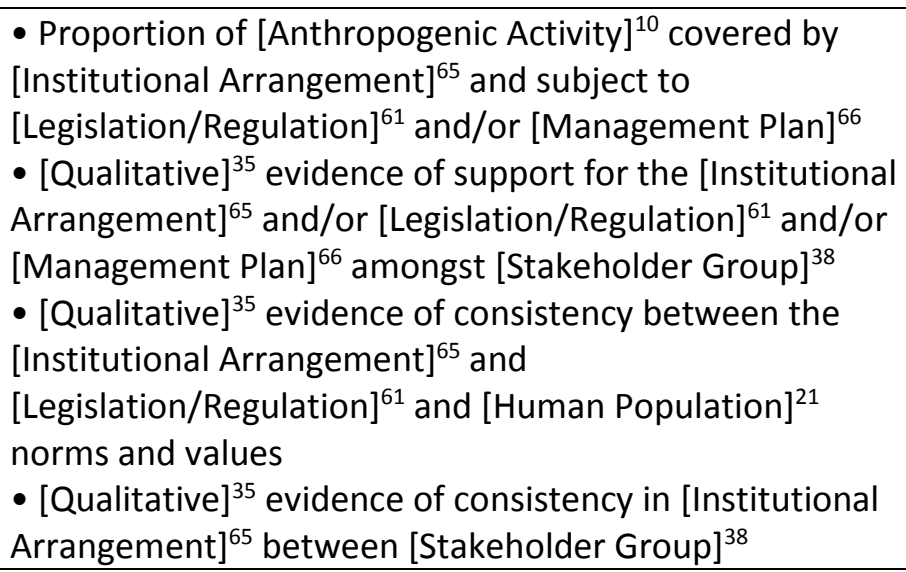 \\
\hline & $\begin{array}{l}\text { Resources: Funding and } \\
\text { other support is } \\
\text { adequate and reliable }\end{array}$ & $\begin{array}{l}\text { - Level and duration of [Support] }{ }^{67} \text { for [General } \\
\text { Management Activity] }{ }^{68} \text { and/or [Fisheries Management } \\
\text { Activity] }{ }^{69} \text { amongst [Stakeholder Group] }{ }^{38} \text { and/or [Human } \\
\text { population] }{ }^{21} \text { at [Human Geographic Region] }{ }^{22} \\
\text { - Types of [Conflict Resolution Approaches] }{ }^{70} \text { available to } \\
\text { deal with disputes }\end{array}$ \\
\hline & $\begin{array}{l}\text { Agreements: } \\
\text { Agreements between } \\
\text { participants are } \\
\text { comprehensive and } \\
\text { enforceable }\end{array}$ & $\begin{array}{l}\text { - } \text { [Quantification] }^{12} \text { of agreements involving [Stakeholder } \\
\text { Group] }{ }^{38} \text { and/or [Human Population] }{ }^{21} \text { containing } \\
\text { [Agreement Element] }^{71} \\
\text { - }\left[\text { Quantification] }{ }^{12} \text { of agreements involving [Stakeholder }\right. \\
\text { Group] }{ }^{38} \text { and/or [Human Population] }{ }^{21} \text { supported by }\end{array}$ \\
\hline
\end{tabular}




\begin{tabular}{|c|c|c|}
\hline & & $\begin{array}{l}\text { [Institutional Arrangement] }{ }^{65} \text { and/or } \\
\text { [Legislation/Regulation] }^{61}\end{array}$ \\
\hline \multirow[t]{7}{*}{ Process } & $\begin{array}{l}\text { Collaborative: } \\
\text { Collaborative } \\
\text { relationships within and } \\
\text { between governments } \\
\text { and other parties }\end{array}$ & 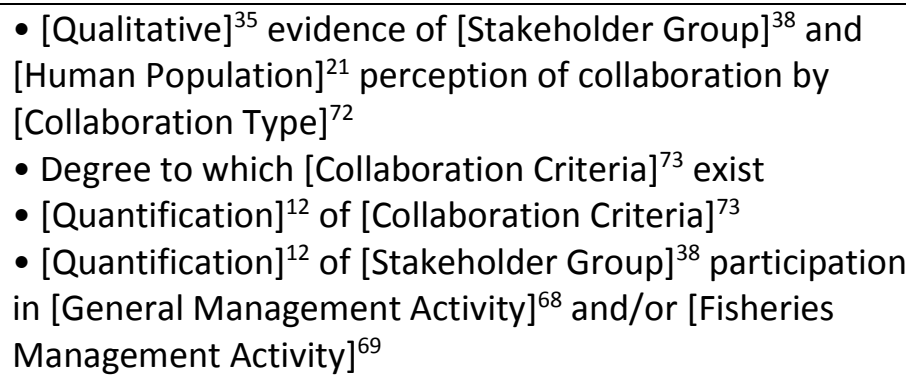 \\
\hline & $\begin{array}{l}\text { Co-operation: Best } \\
\text { efforts are made to } \\
\text { address conflicts } \\
\text { between stakeholders }\end{array}$ & 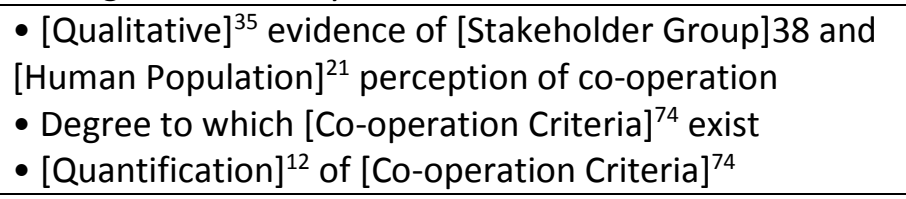 \\
\hline & $\begin{array}{l}\text { Inclusive: Inclusive } \\
\text { processes that support } \\
\text { participation }\end{array}$ & 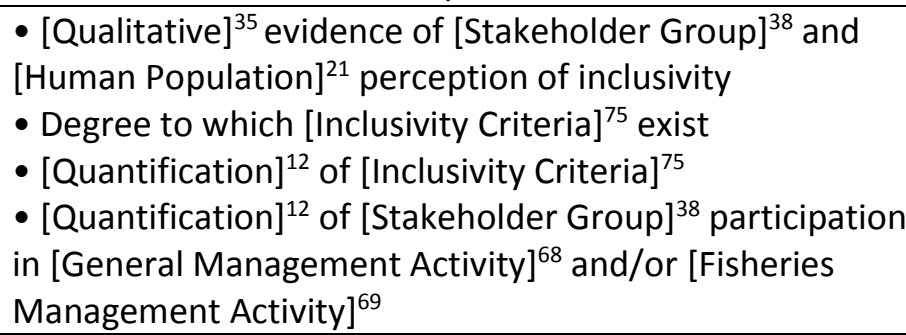 \\
\hline & $\begin{array}{l}\text { Informed: Stakeholders } \\
\text { have access to best } \\
\text { available information } \\
\text { and analysis }\end{array}$ & 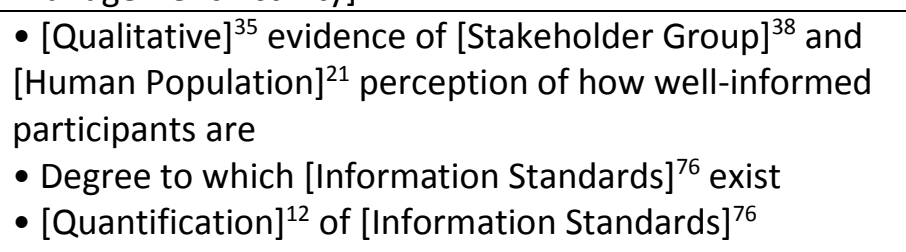 \\
\hline & $\begin{array}{l}\text { Predictable: Predictable } \\
\text { and consistent decision- } \\
\text { making procedures that } \\
\text { are not changed } \\
\text { without adequate } \\
\text { consultation or } \\
\text { justification }\end{array}$ & $\begin{array}{l}\text { - }[\text { Qualitative }]^{35} \text { evidence of [Stakeholder Group] }{ }^{38} \text { and } \\
\text { [Human Population] }^{21} \text { perception of } \text { [Predictability } \\
\text { Criteria] } \\
\text { - Documentation of [Access] }{ }^{41} \\
\text { - Documentation and[Quantification] }{ }^{12} \text { of changes to } \\
\text { [Access] }^{41} \\
\text { - Existence of [Management Plan] }{ }^{66} \\
\text { - Documentation and [Quantification] }]^{12} \text { of changes to } \\
\text { [Management Plan] }^{66}\end{array}$ \\
\hline & $\begin{array}{l}\text { Flexible: Flexible and } \\
\text { responsive processes } \\
\text { that can be adapted to } \\
\text { changing circumstances }\end{array}$ & $\begin{array}{l}\text { - [Qualitative] }]^{35} \text { evidence of [Stakeholder Group] }{ }^{38} \text { and } \\
\text { [Human Population] }{ }^{21} \text { perception of flexibility } \\
\text { - Degree to which there is [Flexibility Criteria] } 7^{8}\end{array}$ \\
\hline & $\begin{array}{l}\text { Transparent: Open and } \\
\text { transparent policies, } \\
\text { procedures, decisions, }\end{array}$ & $\begin{array}{l}\left.\text { - [Qualitative] }]^{35} \text { evidence of [Stakeholder Group }\right]^{38} \text { and } \\
\text { [Human Population] }^{21} \text { perception of transparency } \\
\text { - Degree to which there is [Transparency Criteria] }{ }^{79} \\
\text { - [Quantification] }{ }^{12} \text { of [Transparency Criteria] }{ }^{79}\end{array}$ \\
\hline
\end{tabular}




\begin{tabular}{|c|c|c|}
\hline & $\begin{array}{l}\text { and supporting } \\
\text { documentation }\end{array}$ & \\
\hline \multirow[t]{5}{*}{ Outcomes } & $\begin{array}{l}\text { Compliance: Regular } \\
\text { evaluation of and } \\
\text { reporting on } \\
\text { compliance with legal, } \\
\text { regulatory and policy } \\
\text { framework }\end{array}$ & 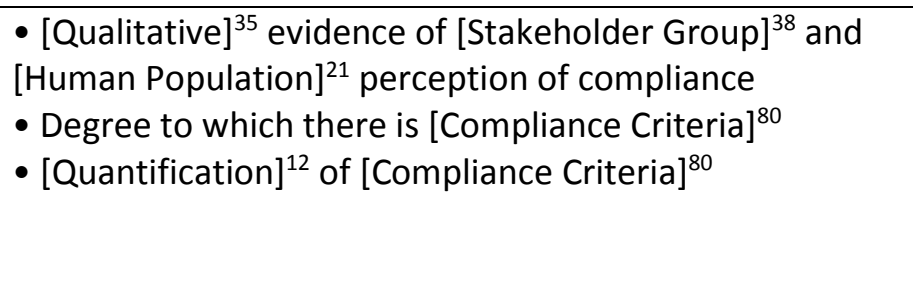 \\
\hline & $\begin{array}{l}\text { Power dynamics: } \\
\text { Explicit consideration of } \\
\text { power dynamics in } \\
\text { decision-making }\end{array}$ & 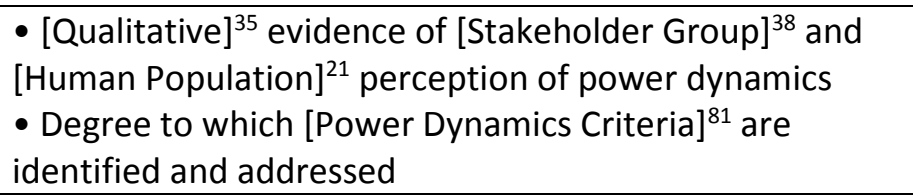 \\
\hline & $\begin{array}{l}\text { Appropriateness: } \\
\text { Explicit consideration of } \\
\text { constitutional, } \\
\text { collective, and } \\
\text { operational levels in } \\
\text { decision-making }\end{array}$ & $\begin{array}{l}\text { - [Qualitative }]^{35} \text { evidence of [Stakeholder Group] }{ }^{38} \text { and } \\
\text { [Human Population] }^{21} \text { perception of appropriateness } \\
\text { - Presence/absence of role for [Stakeholder Group] }]^{38} \text { in } \\
\text { the development, establishment and enforcement of } \\
\text { rules at the [Rule Level] }{ }^{82} \\
\text { - Degree to which [Accredited Organization Criteria] }{ }^{83} \\
\text { was consulted in the development, establishment and } \\
\text { enforcement of rules at the [Rule Level] }{ }^{82} \\
\text { - Degree to which [Stakeholder Group] }{ }^{38} \text { role in the } \\
\text { development, establishment and enforcement of rules at } \\
\text { the [Rule Level] }{ }^{82} \text { is commensurate with impact of rule on } \\
\text { the [Stakeholder Group] } \\
\text { - Degree to which there is [Flexibility Criteria] }{ }^{38}\end{array}$ \\
\hline & $\begin{array}{l}\text { Trade-offs: Explicit } \\
\text { consideration of trade- } \\
\text { offs in decision-making }\end{array}$ & 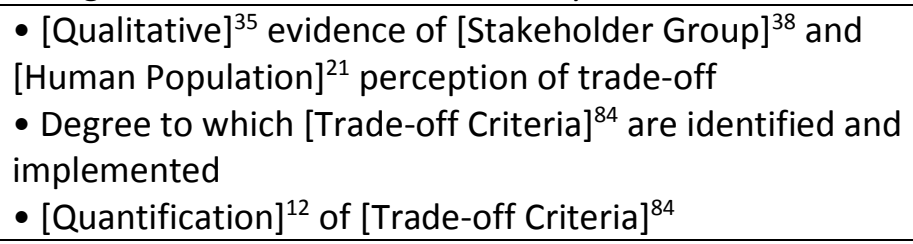 \\
\hline & $\begin{array}{l}\text { Assessment: Regular } \\
\text { evaluation of and } \\
\text { reporting on outcomes } \\
\text { in the ecological, } \\
\text { community, and } \\
\text { institutional dimensions } \\
\text { of the fishery }\end{array}$ & $\begin{array}{l}\text { - [Qualitative }]^{35} \text { evidence of [Stakeholder Group] }{ }^{38} \text { and } \\
\text { [Human Population] }{ }^{21} \text { perception of assessment } \\
\text { - [Quantification] }]^{12} \text { of [Fishery Category] }{ }^{14} \text { subject to } \\
\text { assessment } \\
\text { - Degree to which [Assessment Method] }{ }^{85} \text { exists } \\
\text { - [Quantification] }]^{12} \text { of recommendations from evaluation } \\
\text { addressed in subsequent management activities }\end{array}$ \\
\hline
\end{tabular}

\section{ATTRIBUTES}

1. Status: Bt/Btarget; Bt/Blim; Bt/B0; Probability of Extinction; COSEWIC/SARA designated unit status

2. Resource Demographic Category: species; population; stock; size; sex; age class 
3. Resource Geographic Region: province; country; Exclusive Economic Zone; region; management area; marine area; river system; lake; watershed

4. Index of Abundance: CPUE; WPUE; survey estimates; stock assessment biomass/abundance estimates

5. Time Period: day; week, month; season; year; decade; century

6. Recruitment Dynamics: compensation or depensation; changes in average recruitment

7. Genetic Diversity: genetic variation using microsatellites and mitochondrial DNA; genetic mixing; genetic sex ratio

8. Phenotypic Diversity: phenotypic variation in measurable characteristics; maturation-at-age; size-at-age; phenotypic sex ratio

9. Biodiversity Indices: species richness; Shannon's diversity; species assemblage structure

10. Anthropogenic Activity: harvesting; shipping; tourism and recreation; oil and gas extraction/processing; mining; forestry; aquaculture; construction; residential development

11. Benthic Species: corals; sponge; crystalline algae

12. Quantification: proportion; number; frequency; total area; total volume; presence/absence; ratio

13. Gear: nets; traps; hooks; longline; trawl; troll; gillnet; seine; trap; hook and line; dive

14. Fishery Category: fishery (by species, gear, market); fleet (by vessel size, ownership, gear)

15. Pollution: thermal \& heated water; sewage; debris; oil discharge; noise; light

16. Food-web Interactions: Interaction Strength; Metabolic Respiration; energy flow; carbon flow

17. Food-web Stability: CV of biomass; Eigenvalue from Community Matrix Interactions.

18. Regime Shift Indicators: CV of biomass; Average Trophic Level; Length of fish; End-to-End Ecosystem Models; Ecosystem Exploitation Index

19. Eutrophication evidence: nutrient concentrations; hypoxia; algal blooms; changes phytoplankton communities; fish kills.

20. Social Factor: suicide rate; infant mortality rate; unemployment rate; migration rate; employment rate; life expectancy; real per capita income; job satisfaction level employment rate; life expectancy; real per capita income; job satisfaction level

21. Human Population: general human population; fisheries participants; aboriginal people; youth; women; coastal communities

22. Human Geographic Region: country; province; region; community; First Nation territory

23. Services: education; housing; daycare; medical care

24. Education: primary school, some high school; high school graduate; some postsecondary; postsecondary certificate or diploma; bachelor's degree; master's degree; PhD

25. Seafood: by species grouping (e.g., salmon, groundfish); species (e.g., chum salmon, prawns); gear and species (e.g., gillnet-caught chum salmon)

26. Adjacent: within 10 miles; within 100 miles; in province; in country

27. Product Category: landed; processed; available for sale; consumed; exported from

28. Processing Type: fresh; fresh-frozen; frozen-at-sea; smoked; fish product (e.g., surimi); canned; fishmeal

29. Certification Standards: occupational first aid; marine emergency duties; master's ticket; engineer's ticket

30. Data: federal fisheries data that does not violate privacy, confidentiality or national security requirements; federal fisheries catch data; federal; fisheries stock assessment data; federal fisheries quota transaction data; provincial fisheries processing data; fisheries ownership data

31. Fishery Related Website: DFO website; industry association website; community association fisheries website; ENGO fisheries website

32. Organization Condition: number of; participation rates in; funding for

33. Organization: arts organizations; cultural institutions; social organizations; environmental organizations; political organizations; industry associations

34. Jurisdiction: federal; provincial; municipal; First Nation 
35. Qualitative: survey; focus group; interview; public hearing; public inquiry; study; legal proceedings; media article

36. Well-being Index: OECD Better Life Index; Genuine Progress Index; Gross National Happiness; Human Development Index

37. Economic Unit: Individual; enterprise; fishery; industry

38. Stakeholder Group: Aboriginal communities; Industry; Resource Users; Regional government; Community groups; Environmental interests; Provincial Government

39. Compensation: payment; wage; share; bonus

40. Sector: commercial; recreational; food; cultural

41. Access: open access; licence; quota; individual property right; hereditary right; communal property right

42. Operator Type: processor with fisheries access rights; non-participating access owner (investor); owneroperator; active fishermen without ownership access

43. Fisheries Related Private Infrastructure: vessels; processing plants; service providers; manufacturers 44. Fisheries Related Public Infrastructure: wharves, docks, piers; coast guard facilities; research stations and vessels; stock enhancement facilities

45. Benefit Axis: employment; access (quota, licence); physical capital (e.g., vessels); income; revenue; food; opportunity

46. Socio-economic Distribution Axis: gender; age; sector; fishery; region; community; enterprise; vessel; harvester; individual

47. Cost Axis: loss of capital; loss of human life; human health impacts; habitat loss; ecosystem service losses; opportunity costs; foregone revenues

48. Value Type: landed value; export value; wholesale value; retail value

49. Value Chain Element: producer; processor; wholesaler; retailer; consumer; investor

50. Risk Axis: ecological; financial; economic; health; cultural

51. Livelihood Index: Sustainable Livelihood Security Index; Economic Security Index

52. Human Demographic Axis: age; sex; place of residence; aboriginal status; education; income level

53. Occupational Axis: skipper; deckhand; tenderman; diver; shoreworker; technician; fisheries observer;

fisheries scientist; processor;

fisheries manager; fisheries researcher

54. Productivity: labour productivity; multi-factor productivity; capital productivity

55. Efficiency: allocative efficiency; productive efficiency; technical efficiency

56. Financial ratio: cash ratio; current ratio; effective tax rate; return on equity; debt to equity; cash flow to debt; price/earnings ratio; dividend yield

57. Agreement: conditional sales agreement; trust agreement; minimum price agreement; collective agreement

58. Experience: months or years working in industry; position (deckhand, skipper); fisheries

59. Labour tactic: strike; blacklist; boycott

60. Financial Information: licence value; quota value; share value; wages; price; revenues; costs; profits; stock status

61. Legislation/Regulation: Fisheries Act; Oceans Act; Marine Stewardship Council (MSC) requirements; industry association regulations

62. Market Failure: corporate concentration; insider trading; undue market control; transfer pricing; price

gouging; price-fixing

63. Enforcement: arrest, prosecution, fine, jail term

64. Economic Variables: price; rent; subsidies; externalities; consumer surplus; producer surplus

65. Institutional Arrangement: legislation; regulation; policy; programs; management structures

66. Management Plan: IFMP; marine use plan; land use plan

67. Support: financial; human resources; technical; logistical 
68. General Management Activity: planning; policy-making; data collection; research and analysis; decisionmaking; audit and evaluation; training; administration; communications

69. Fisheries Management Activity: monitoring; enforcement; stock assessment; research; habitat monitoring; habitat protection; habitat restoration; habitat enhancement; harvest planning; harvest management

70. Conflict Resolution Approaches: Facilitative approach; Mediation; Negotiation; Arbitration; Rights based

Court system; Rule based processes; Transformative approach; Interest based approach; Evaluative approach; Activist approach; Narrative approach

71. Agreement Element: goals \& objectives; terms of reference; statement of roles and responsibilities; duration and renewal conditions; liability and accountability provisions; dispute resolution mechanisms; audit and evaluation conditions

72. Collaboration Type: public-private partnerships; private-social partnerships; co-management

73. Collaboration Criteria: power-sharing; information-sharing; shared rule-making; multi-party agreements signed and/or renewed; multi-party management plans

74. Co-operation Criteria: disputed decisions; disputes resolved; availability of third party conflict resolution services; use of third party conflict resolution services; ministerial intervention

75. Inclusivity Criteria: access to funding; access to other resources; attendance at meetings; participation rates at public hearings; travel time between fishing communities \& meeting locations; membership in stakeholder groups

76. Information Standards: allocation decisions include explicit trade-off analysis; decisions include risk assessment; peer review of science; knowledge of legal and regulatory framework; indicators are SMART; use of EBM approaches; application of Precautionary Approach; incorporation of local and traditional knowledge; multi-disciplinarity; MSE; Bayesian Decision Networks

77. Predictability Criteria: clearly established and communicated processes for decision making; following plain meaning of a process or provision; pursue process as it was intended by drafters; follow precedent

78. Flexibility Criteria: adherence to process and precedent; consideration of range, time, change, conditions of uncertainty and favourability; consideration of trigger events, trigger states, decisions and choices; distinguish between flexible, inflexible and degrees of flexibility

79. Transparency Criteria: availability of information; usability of available information; public release of rationale for decision

80. Compliance Criteria: conformation to rules, regulations, plans, policies, standards, agreements, laws and administrative specifications; requirement of and conformity to covenants of permits, certificates, licenses or leases; penalties in place to address infractions such as fines, seizure of harvest

81. Power Dynamics Criteria: sources of power imbalances (personal, relational, data, technological, professional, structural, educational, capacity etc.); types of power relations (citizen, delegated or power over, partnership or power with, powerless, empowered, coercive, cooperative); power holders

82. Rule Level: constitutional level; collective level; operational level

83. Accredited Organization Criteria: represents members; requires members to pay an annual due; maintains a duly elected executive; has established and maintains a reporting mechanism; has made required filings and registration with appropriate public bodies; maintains minimum membership size

84. Trade-off Criteria: qualitative and quantitative frameworks to discuss trade-offs; clarified decision context; clear statement of and justification for trade-offs; evaluation and selection of trade-offs; assignment of ranks or preferences for alternatives; estimation of risk (objective and subjective)

85. Assessment Method: performance based audit; program evaluation; fishery management plan evaluation; third-party fisheries certification assessment; management strategy evaluation; CFRN indicator framework . 